\title{
THE TREATISE ON THE HISTORY OF SPANISH BY B. DE ALDRETE (1606) AS THE FIRST TEXTBOOK OF ROMANCE PHILOLOGY
}

\author{
M.A. Kossarik \\ Moscow State University, \\ Philological faculty, 1-51, ul. Leninskie Gory, 119991, Moscow
}

\begin{abstract}
The paper analyses the role of B. de Aldrete's treatise "Del Origen y principio de la lengua castellana o romance que oi se usa en España" (1606) in the development of Romance philology.

The XVII-century author writes about the most important aspects of internal and external history of Spanish, such as: pre-Romance Spain and substratum languages; Roman conquest and romanization; Hispanic Latin; German conquests of Spain; Arabic conquest and the Reconquista; formation of kingdoms in the north and state-building processes; sociolinguistic situation in Spain; the role of Spanish in the New World; changes from Latin to Spanish in phonetics and morphology; sources of Spanish lexis; early written texts; territorial, social, functional variation of Spanish.

Apart from the aspects of Spanish philology, B. de Aldrete pays attention to the formation and functioning of Pyrenean languages: Catalan, Galician, and Portuguese. However, B. de Aldrete does not limit himself to examining Ibero-Romance languages. Many aspects of the history of Spanish are shown against a wider, Romance background, bearing in mind the earlier tradition (the Antiquity, in the first place). He also confronts Spanish with other Romance languages and Latin.

The analysis of the first treatise on the history of Spanish makes one reconsider B. de Aldrete's contribution to the development of language description models and the bases of Romance philology. The treatise sets up a model of Romance philology as a full-fledged philological discipline.
\end{abstract}

Key Words: Romance philology, Romance linguistics, history of Spanish, Spanish language, linguistic historiography, history of linguistics

For citation: Kossarik M.A. 2020. The Treatise on the History of Spanish by B. De Aldrete (1606) as the First Textbook Oo Romance Philology. Philological Sciences at MGIMO. Vol. 6. No 4(24). P. 135-145. https://doi.org/10.24833/2410-2423-2020-4-24-135-145

\section{ТРАКТАТ ПО ИСТОРИИ ИСПАНСКОГО ЯЗЫКА Б. ДЕ АЛЬДРЕТЕ (1606) КАК ПЕРВОЕ СОЧИНЕНИЕ ПО РОМАНСКОЙ ФИЛОЛОГИИ}

М.А. Косарик 
Московский государственный университет имени М. В. Ломоносова, филологический факультет, 119991, Москва, ул. Ленинские горы, 1-51.

\begin{abstract}
Аннотация. В статье рассматривается роль трактата Б. де Альдрете "Del Origen y principio de la lengua castellana o romance que oi se usa en España" 1606 г. в зарождении романской билологии. Автор XVII в. представляет важнейшие аспекты внешней и внутренней истории испанского языка: Испания до прихода римлян и языки дороманского населения; римское завоевание и романизация; характер пиренейской латыни; Испания после прихода германиев; Арабское завоевание и Реконкиста; образование королевств на севере и становление единого государства; особенности соииолингвистической ситуации Испании; роль испанского языка на новооткрьтых территориях; изменения от латыни к испанскому в бонетике и морфологии; источники испанской лексики; ранние письменные памятники; территориальное, соииальное, функииональное варьирование испанского языка.

Помимо проблематики кастильского Б. де Альдрете останавливается на фактах формирования и функиионирования языков Пиренейского полуострова: каталанского, галисийского, португальского.

Однако Б. де Альдрете не ограничивается вниманием к иберо-романским языкам. Многие явления истории испанского языка он представляет на широком романском боне, опираясь на предшествуюшую традицию, в первую очередь, античную, сопоставляет испанский с латьнью и с другими романскими языками.

Проведённый анализ первого сочинения по истории испанского языка выявляет вклад Б. де Альдрете в разработку модели описания истории языка, а такне основ романского языкознания: автор закладьвает приниипы романской филологии как научной дисциплинь.
\end{abstract}

Ключевые слова: романская филология, романское языкознание, история испанского языка, испанский язык, тингвистическая историография, история языкознания

Для цитирования: М.А. Косарик 2020. Трактат по истории испанского языка Б. Де Альдрете (1606) как первое сочинение по романской филологии. Филологические науки в МГИМО. Том 6. № 4(24). С. 135-145. https://doi.org/10.24833/2410-2423-2020-4-24-135-145

$\mathrm{T}$ руд Б. де Альдрете, каноника из Кордовы, оценивается прежде всего как первое сочинение по истории языка $[9 ; 10 ; 16 ; 17 ; 21]$; как один из первых трактатов по языковой политике $[11 ; 18 ; 20]$; как вклад в общелингвистическую проблематику [19; 6]. Однако остаётся недооценённой роль испанского филолога в формировании романистики: отдельные вопросы затрагивались, но последовательного анализа сочинения с этих позиций не проводилось.

Трактат состоит из трёх книг, представляющих историю испанского языка: Испания в Римской империи, приход германцев, арабское завоевание и Реконкиста, становление государства; некоторые аспекты социолингвистической ситуации на Пиренейском полуострове и распространения испанского в Новом свете; изменения языковой системы от латыни к испанскому (фонетика, морфология, источники испанской лексики). Испанская и, шире, иберо-романская проблематика рассматривается автором на общероманском фоне.

Сочинение Альдрете может служить материалом для исследования процесса формирования романистики как современной науки. Задача статьи - проследить, как в рамках описания истории одного романского языка закладываются основы изучения романской филологии ${ }^{1}$.

Б. де Альдрете предваряет изложение формирования испанского языка из латыни замечанием, отражающим связь языка с историей страны², что является одним из основных принципов

\footnotetext{
1 Текст трактата часто заставляет вспомнить о фундаментальных работах по романскому языкознанию [2], об учебниках и программах по романской филологии $[1 ; 4]$.

2 Romance [...] fe derivò de la lengua Latina, ò Romana, i della tuuo su principio, i nombre. [...] muchos años en España fue vulgar la legua Latina [...] Con la venida de los Vandalos, i Godos, como se mudò el imperio, tambien la lengua, pero no del todo, fino facando della la vulgar [8, c. 6].
} 
изучения истории языка. Автор пишет о римском завоевании, о местных племенах. Переходя к внутренней истории языка, к изменениям латинской языковой системы, он сообщает о субстратных языках, что с позиций романистики представляется вполне закономерным. Альдрете перечисляет языки дороманских народов ${ }^{3}$ и зоны их распространения [8, с. 227-229], в связи с топонимикой упоминает пузитан и ареваков [8, с. 298-299]. Сведений о фонетике и морфологии субстратных языков автор XVII в. не даёт, но, приводя примеры изменений топонимики на протяжении истории, пишет о дороманских и «романизованных» топонимах ${ }^{4}$ (примечательно употребление термина, обозначающего одно из ключевых понятий романской филологии). Внимание к субстрату Пиренейского полуострова отчасти распространяется на другие зоны Романии: Галлию, Италию [8, с. 72-78, 232-241].

Альдрете начинает описание римского завоевания с соперничества Рима и Карфагена; представляет ход завоевания, отмечая более длительное покорение Севера и необходимость держать здесь легионы; представляет деление на провинции, статус и количество римских и латинских муниципиев и колоний, пуэблос с автохтонным населением [8, с. 7-37].

До подробного описания собственно истории испанского языка Альдрете обращается к проблематике латыни (генетической основы романских языков): её апологии и, что особенно важно для автора, её роли как языка государства [8, с. 42-53], распространению латыни в Италии и за её пределами, степени романизации и характеру латыни провинций, языковой политике Рима. Это очень показательно для понимания роли Б. де Альдрете в формировании романистики как общей дисциплины, лежащей в основе изучения отдельных романских языков.

Испанский филолог пишет о вытеснении римлянами языков других народов - сначала с близлежащих территорий (этрусского из Тосканы, оскского из Кампаньи, греческого из Калабрии), затем со всей территории Апеннинского полуострова в результате длительной борьбы (автор упоминает о войнах на территории Италии, в том числе, с Ганнибалом).

Внимание уделено Италии, рассматриваются распространение латыни в Римских провинциях, средства вытеснения местных языков (употребление только латыни в официальном общении, в судопроизводстве) [8, с. 53-56], проблематика латыни как языка культуры, образования. Вопросы эти оказываются весьма актуальными для испанского автора начала XVII в., поскольку трактат создаётся на пике могущества империи Габсбургов, в условиях распространения испанского языка за пределы Испании, и Альдрете проводит параллели между ролью испанского языка и латыни в Римской империи.

Обращаясь к галло-романскому ареалу, испанский автор представляет складывающуюся здесь социолингвистическую ситуацию. В описании отражены различия во времени завоевания и степени романизации частей Галлии, деление на провинции ${ }^{5}$; отмечено длительное сохранение кельтского, но подчёркиваются связи с Римом и знание, особенно в Аквитании и Нарбоннской Галлии, латинской литературной, грамматической и риторической традиции. Альдрете утверждает безусловное происхождение французского от латыни, пишет о завоевании франков и утрате ими германского языка, о связях Франкского королевства Карла Великого с Римом, о Страсбургских клятвах $[8$, с. 71-82], доведя описание до начала французской письменности.

Представив эти важнейшие для романской филологии темы, Б. де Альдрете переходит к истории испанского языка.

В трактате описаны история римского завоевания и умиротворения Пиренейского полуострова, административное деление на провинции ${ }^{6}$, социолингвистическая ситуация: первоначальный билингвизм ${ }^{7}$, разновременность романизации: ранняя и глубокая в Бетике (Андалусии) и более

\footnotetext{
Упоминает басков, кантабров, кельтов, кельтиберов, турдетан.

I nosotros no defendemos tan gran mudança, i la alteracion en la lengua, como la ai en los lugares. De mas de que, aun los que oi los tienen fon romaniçados al talle de las de mas palabras Latinas, de Toletum, dizemos Toledo, de Corduba, Cordoua de Malaca Malaga; de Pallantia Palencia $\& c$, Muchos ai que en efte tiempo an tenido tres nombres, i lo que mas es la prouincia principal Turdetania, Boetica, i Andalucia [8, c. 228]. 
поздняя на гористом севере ${ }^{8}$. Автор показывает растущее влияние Рима: колонизация латинянами, италиками-осками; множество римских и латинских колоний; получение местными жителями гражданства; распространение латыни в сельской местности [8, с. 123-124]; большое число выдающихся испано-римлян ${ }^{9}[8$, с. 104-127].

Альдрете эксплицирует современное понимание романизации: переход на латынь в результате усвоения римского образа жизни, культуры ${ }^{10}$ и объясняет утверждением латыни в качестве родного языка её сохранение после германского завоевания [8, с. 85].

Сведения о германцах скорее касаются империи в целом, относительно Испании Альдрете сообщает об отсутствии сопротивления, зонах расселения, об уровне культуры германцев ${ }^{11}$, быстро утративших свой язык, и сразу переходит к социолингвистической тематике. Автор отражает ситуацию диглоссии: все официальные документы пишутся на латыни ${ }^{12}$, которая претерпевает значительные изменения, «порчу»; письменность на формирующемся из латыни romance отсутствует $^{13}$. Альдрете подчёркивает языковое единство полуострова эпохи вестготов [8, c. 164).

На социолингвистической ситуации сосредоточен филолог и при обращении к арабскому завоеванию: он пишет о разделении полуострова на юг (здесь превалирует арабский, но христиане сохраняют романскую речь) и север, где продолжает развиваться romance [8, с. 142-143].

Б. де Альдрете отражает значение первых веков после падения Римской империи - эпохи вестготского королевства и Реконкисты - как времени формирования пока ещё бесписьменного, воспринимаемого как испорченный латинский romance $^{14}$, или кастильского [8, c. 157], и фиксирует момент появления кастильской письменности, упоминая создание перевода Библии, "Siete Partidas", "Cronica General de España” в правление Альфонсо X Мудрого [8, с. 156].

К эпохе Реконкисты относит Б. де Альдрете образование ареалов трёх иберо-романских языков (португальского, каталанского, кастильского) [8, с. 143, 164-165]. Он подчёркивает различие каталанского и кастильского, указывает зоны распространения, отмечает и существование баскского. Особенности каталанского и португальского он объясняет языковыми контактами с французами из-за их участия в Реконкисте Галисии и Каталонии. Упоминая об исторической близости каталанского и языка Лангедока, такой связи португальского и галисийского испанский автор не признаёт ${ }^{15}$.

Рассмотрев условия формирования языка, Альдрете обращается к изменениям в языковой системе от латыни к романскому, причину изменений автор видит в языковых контактах ${ }^{16}$.

Признавая изменения в фонетике и лексике, автор считает характерными чертами романской речи изменения в морфологии: исчезновение падежного склонения имени, утрату синтетиче-

\footnotetext{
8 no fe recibio igualmente la lengua Latina en Efpaña, porque no fe pacificaron ni acomodaron todos a vn tiempo con el nueuo traje i lengua [...]. La primera que lo recibio todo fue nueftra Andalucia [...]. La parte que mas tarde figuio lo que los demas fue la feptemtrional hazia las montañas [8, c. 99].

9 Марциал, Квинтилиан, Сенеки, Лукан, Пруденций, Порций Латрон, Помпоний Мела, Колумела, императоры Траян, Адриан.

${ }^{10}$ todos los Romanos la tuuieron [la lengua Latina] por vulgar [родной язык], i lo mismo todos aquellos que fe preciaron defte nombre, i fueron con el trato i communicacion paffandofe a biuir con ellos [...] i fe acomodauã al ufo de fus leies, i gozauan de priuilegios de ciudadanos Romanos, i tambien los que eran naturales de Roma o de Italia i paffauan apoblar en las prouincias. En las que tenian mas paz i menos impedimentos crefcia efto cada dia mas, hafta llegar algunas a perder la lengua antigua quedandofe con la Romana [8, c. 84]. fiendolo los Efpañoles fe reduxeron a las coftumbres, lengua, derecho, i jurifdicion de los Romanos [8, c. 94].

${ }^{11}$ Salieron mui mal con la lengua Latina efta gente, mas dada a las armas, que a las letras [8, c. 153]. gente mas belicofa, i fenzilla, que ambiciofa, [...] fu poca policia $[8$, c. 360]

12 Fuero Juzgo [...] leies que los Godos Reies de España hicieron [8, c. 159].

${ }^{13}$ en aquel tiempo, i muchos figlos defpues, no fe efcriuio por letra en aquel Romance, de que fe iua forjando el que ahora ufamos corrompido de la lengua Latina, fino todo lo que fe daua por efcrito era en Latin [8, c. 142].

${ }^{14}$ Romance Latin corrompido [...] en aquel tiempo, i muchos figlos defpues, no fe efcriuio por letra en aquel Romance, de que fe iua forjando el ahora ufamos corrompido de la lengua Latina [8, c. 142].

${ }^{15}$ En Cataluña, para la conquifta [...] el Romance fe mefclò con la lengua Francesa, de que fe refultò aquella lengua mui femejante, i poco diferente de la de Lenguadoc, o Narbonenfe, de donde a quella tiene parte de fu origen [.... en Portugal ai otra lengua [...] mefcla de la Francefa [8, c. 165166).

${ }^{16}$ Romanos [...] introduxeron fu lengua, pero [...] recibio mucho daño en la lengua [...] cada vna de las gentes, que fueron fugetas al Imperio, lleuò a Roma los vicios, i faltas de fu lengua [...]. Con la venida de los Godos, i otras barbaras naciones a Italia, i a las provincias del Imperio [...] los vencedores [...] procuraron aprender la Latina, que fe les dio mui mal, i la corrompieron, i vnos, i otros cada vno por diuerfo camino, vinieron a dar principio a la lengua Italiana, i Caftellana [8, c. 150-151].
} 
ских форм залога, образование аналитических форм глагола при выражении предшествования ${ }^{17}$. Альдрете подчёркивает латинское происхождение большей части словарного состава (perfona, mundo) и отмечает существование слов, чья связь с латинским не столь очевидна из-за происходивших изменений (nuestro) [8, с. 196-197].

Б. де Альдрете описывает фонетические изменения от латыни к испанскому ${ }^{18}$, спорадически приводит факты итальянского, французского и объясняет сходства общим происхождением от латыни [8, с. 210-212], предвосхищая таким образом принципы исторической фонетики: выявление регулярных фонетических процессов (что приближается к идее фонетических законов) и соответствий в родственных языках. Это сближает испанского филолога с более ранними ренессансными авторами описаний итальянского, французского, португальского: Толомеи ("Il Cesano de la lingua toscana" 1520-е, публикация 1555; "Il Polito" 1525 г.) [3], Дюбуа ("In linguam Gallicam Isagoge” 1531) [7], Нунешем де Леан (“Orthographia” 1576; “Origem da lingoa portuguesa” разрешение публикации 1601, публикация 1606) [14; 15].

Изменения от латыни к романскому в слово- и формообразовании представлены как изменения конкретных слов: Альдрете приводит латинские и испанские слова, различающиеся словообразовательными моделями, сопоставляет отдельные грамматические формы испанского, итальянского, французского ${ }^{19}$.

Наибольшее внимание Альдрете уделяет источникам испанской лексики. Он подчёркивает латинскую основу словарного состава, рассматривает заимствования, которые считает средством обогащения языка, признаёт особую роль грецизмов, сравнивает релатинизацию с проникновением грецизмов в латынь ${ }^{20}$. Обращаясь к германизмам, Альдрете связывает с цивилизационным уровнем готов изменения в готском и латыни ${ }^{21}$, чем объясняет трудности определения германизмов в romance [8, с. 361-362]. Альдрете приводит два списка арабизмов (арабизмы в испанском, романизмы в арабском), считая, что заимствования в языках идут в обоих направлениях [8, с. 362-363]. Особое место в трактате уделено топонимике. Автор предлагает толкования, связанные с историей Испании, Италии, Греции, с античной мифологией, библейской историей, но очень многие из них ошибочны.

Трактат позволяет оценить вклад Б. де Альдрете в разработку общих вопросов романской филологии.

В трактате используются разные номинации со значением «язык, речь», помимо lengua и lenguaje. При обозначении испанского языка (автор термин español к языку не применяет) конкурируют castellano, lengua castellana, nuestra lengua/lengua nuestra. В названии трактата видим "romance que oi se usa en España" (иногда автор относит к современному испанскому romance без уточнений, если это очевидно из контекста).

Однако часто romance встречается в другом значении. Альдрете объясняет появление термина необходимостью противопоставить германский язык пришельцев-готов и романский язык населения бывшей римской провинции ${ }^{22}$. С переходом готов на romance утверждается оппози-

\footnotetext{
${ }^{17}$ vnas letras entendian por outras, [...] dexaron la declinacion la que tomaron de fu lengua. En la qual los nombres fon indeclinables, i los casos fe diftinguen por los articulos, i preposiciones, como oi fe vfa en la lengua Italiana, Efpañola [...].totalmente perdieron la voz paffiva, i ufaron de los participios con el verbo fer o auer [...] que usamos en la lengua nuestra, i tambien lo tiene la Italiana, lo qual tambien es de la lengua fetentrional, o Gotica [8, c. 153-154].

${ }^{18}$ dicciones Latinas, que tienen au, las boluieron en, o, aurum, [...] autumnus, [...] caulis, [...] Taurus. De los quales dezimos [...] oro, [...] otoño, [...] coles, [...] Toro [8, c. 205-206].

${ }^{19}$ Los Italianos vfarõ algo desto [...] Laurus, Alloro [8, c. 206]. Dize fe vn mismo origen a todos, por que en los cafos todos correfpondemos a los Latinos, i affi dezimos , io, mi, nos, i nosotros, el Italiano io, me, Noi, i Noi altri, el Frances, ie, moi, Nous [8, c. 214].

${ }^{20}$ Lo mismo pafsa oi en el Romance, que admitimos vocablos Latinos de nueuo o de otras lenguas, o por que faltan en la nuestra los proprios, o porque buscamos, que aia en ella maior abundancia dellos [...]. Despues de ia perficionada admitia de nueuo vocablos conofcidamente Griegos, quando le faltauan los proprios [8, c. 260-261].

${ }^{21}$ Aunque los Godos fueron muchos años feñores de Efpaña, como tambien de Italia, i Frãcia, fiendo gente mas belicofa, i fenzilla, que ambiciofa, procuraron antes cõferuar la lengua Latina que eftender la fuia propria, pero por fu poca policia, i el grande primor, que efta tiene, la vinieron a eftragar i corromper $[8$, c. 360].

${ }^{22}$ Romance [...] fe derivó de la lengua Latina, ò Romana, i della tuuo su principio, i nombre [8, c. 6]. Es tan parecida, i femejante la lengua Castellana a la Latina fu madre [...] i en ambas concurren todas las partes de legitima filiaciõ. [...] Lo primero el nombre de Romance teftifica efto, el qual fe le pufo a diftincion de la Gotica. [...] los Romanos fe diftinguian de los Godos, i en Efpaña no auia otra diftincion fin hazer memoria del nombre de Efpañoles, porque todos eran Romanos [8, c. 186].
} 
ция латынь $\leftrightarrow$ романский язык. Альдрете относит «romance» преимущественно к раннему этапу истории испанского языка (следующем после периода римского владычества в Испании) и подчёркивает использование обозначения в “Siete Partidas"23. Представленная в трактате триада понятий lengua latina - romance - castellano (отмеченная выше конкуренция номинаций ещё не позволяет говорить о сложившейся терминологии) подводит Альдрете к важным инновациям.

Сложившиеся понятия позволяют говорить о формировании представлений об этапах истории романских языков, которые находят отражение в описании истории языка в трактате: 1. римский (с вниманием к доримскому); 2. формирование романской языковой системы; 3. этап становления конкретного романского языка. Рубеж между вторым и третьим этапами - утверждение письменности. Это предвосхищает идею периодизации истории языка (романских языков).

Различение понятий romance, закреплённого за ранним этапом формирования языка из латыни, и romance (que oi se usa en España), обозначающего конкретный романский язык, castellano, создаёт возможность отнести номинацию romance не только к языку, образовавшемуся из латыни в испанском ареале, но и к другим языкам, объединённым общим свойством - происхождением от латыни, что определяет близость этих языков. Таким образом создаётся понятийная основа для особого термина, обозначающего общность романских ${ }^{24}$ языков. В сочинении Б. де Альдрете понятие «романские языки» предстаёт уже вполне сформированным.

Это проявляется в названии одной из глав трактата (“Muestraffe, que la lengua Latina no està del todo en nueftro Romance deftruida” [8, с. 186]), подчёркивающем сходство «нашего Романсе» (кастильского языка) с латынью. Описание отражает системную близость испанского, итальянского и французского, объясняемую общим происхождением от латыни (число имён, выражение падежных значений, сходство романских глагольных систем с латинской); при этом автор отмечает определённые фонетические, грамматические и лексические расхождения между тремя романскими языками ${ }^{25}$.

Б. де Альдрете ставит важный для романской филологии вопрос: к какой именно латыни восходят романские языки. Источником romance он считает разговорную речь, просторечие обычных носителей латыни (то есть народную латынь), отрицая влияние литературной латыни в условиях падения образования в эту эпоху; попутно автор характеризует средневековую латынь' ${ }^{26}$.

Ещё одно обозначение языка, Lengua Vulgar ${ }^{27}$, Альдрете понимает как «родной язык» (синоним - nuestra lengua) и считает применимым к любому языку (латинскому, кастильскому, греческому и др.), когда имеется в виду родной язык.

Сравнение функционирования терминов romance и lengua vulgar в трактате Б. де Альдрете с тем, как они представлены в Словаре Испанской Королевской Академии, в изданиях 1-ом ${ }^{28}$ и

\footnotetext{
${ }^{23}$ Forçoso, i neceffario à fido para mi intento prouar que en Efpaña fue vulgar la lengua Latina [...]. Aora defeo [...] profeguir lo començado, facando de lo dicho los efectos, que fueron principio, i origen del Romance [8, c. 150]. Efte nombre de Romance, por la lengua Caftellana, le hallamos mui ordinariamente en las leies de Partidas [8, c. 186].

24 Термин "Romano" в трактате обозначает «римский».

${ }^{25}$ como las mismas gentes fueron las que vinieron a Italia, Francia, i España, affi cafi igual introduxeron la gramatica, que tiene mui poca diferencia en todas tres prouincias, de manera que no es fola i particular de Efpaña, porque generalmente hablando es vna. Los nombres en todas tres lenguas tienen folas dos terminaciones vna de fingular, $i$ otra de plural, los cafos fe diftinguen por particulas, o preposiciones, que les añaden. Los verbos en fus conjugaciones imitan mucho las Latinas. Lo que mas diftingue eftas tres lenguas, que de la copia, i abudancia de la Latina, vna tomo vnos vocablos, i otra otros, vnos en vna fignificacion, i onros en otra, vnos admite por metafora, otros por traslacion, lo qual no siguio la otra, vna recibio vocablos de los que tenian aquellas gentes, otra no. De los verbos hicieron nombres nueuos, i de las particulas, i otras dicciones compufieron nueuos verbos, vna en la pronunciacion quitò letras, otra las añidio, vna las mudò, otra las conferuò, vna hizo lo que era breue largo, otra al conrario de lo largo breue. Finalmente como los caminos para diuidirfe, i apartarfe fon muchos, affi los vuo para diferenciarfe eftas lenguas, pero en todas fe reconoce el origen de donde decienden, mas o menos manifiefto, fegun le correfponde mas, o menos le parece [8, c. 189-190).

${ }^{26}$ fe iua perdiendo la lengua Latina, i començaua el Romance, teniendo fu principio en la gente popular, i ordinaria, de donde cundio, i fe eftendio por todos. Lo qual fue mui apreffa, por auer fe dexado en aquellos figlos, i cafi acabado los eftudios delas buenas letras, como fe vee en los libros, que de aquellos tiempos tenemos. En los quales, affi en lo que fe trata, como en el eftilo, i modos de hablar fe echa de ver con llaneza [8, c. 158159].

${ }^{27}$ Не совпадает с термином романистики «народная/вульгарная латынь».

${ }_{28}^{28}$ Romance s.m. Nuestro idioma o lengua vulgar. Llámase así por traher su origen de los Romanos. Latín. Lingua Vernacula.
} 
23-ем²9, выявляет очевидную близость автора начала XVII в. к современному пониманию этой проблематики и, соответственно, роль его сочинения в формировании важнейших понятий романистики.

Трактат Б. де Альдрете, одно из первых описаний истории конкретного языка, - яркое подтверждение складывающегося исторического подхода к языку. Автор не только эксплицирует идею подвижности языка, он принадлежит к числу ренессансных лингвистов, считающих историчность универсальным свойством языков ${ }^{30}[14 ; 15]$.

В сочинении Б. де Альдрете, помимо демонстрации близости родного языка к латыни (связанной с апологией, характерной для Ренессанса), появляется новый аспект - сопоставление романских языков.

Автор считает «основными частями языка» лексику и грамматику, которые составляют «материю и форму» языка ${ }^{31}$. Показав латинское происхождение испанских слов, Альдрете, чтобы подчеркнуть близость испанского к итальянскому и обоих - к латыни, проводит последовательное сопоставление латинских, испанских и итальянских именных, местоименных и глагольных парадигм (для наглядности латинские, испанские, итальянские формы набраны разными шрифтами). Описание отражает универсалистское понимание категории падежа (ср. [5, с. 81-90]). Автор поясняет различия средств выражения категории числа имён в трёх языках ${ }^{32}$. Он подчёркивает, что кастильская грамматика является не особой, частной (“particular”), а единой, общей (“una”) с итальянской вследствие одновременного и сходного происхождения от латыни ${ }^{33}$. Близость языков иллюстрируется параллельными текстами молитвы на латинском, испанском (который в данном случае называется romance), итальянском, а также на каталанском и португальском. Таким образом, в историческом сочинении сопоставляются разные уровни (фонетика, морфология, лексика, текст) латыни и романских языков.

Зарождение двух тенденций в описании языков - 1. сопоставительного (типологического), основанного на идеях универсальной грамматики, и 2. исторического, в котором подвижность осознаётся как универсальное свойство языков, - является важнейшей инновацией ренессансной лингвистики [12; 13]. Объединение этих идей у Б. де Альдрете знаменует начальный этап

\footnotetext{
29 Del lat. Romanice 'en el idioma de los romanos'.

1. adj. Perteneciente o relativo a las lenguas romances. Léxico romance.

2. m. Lengua derivada del latín, como el español, el catalán, el gallego, el italiano, el francés, etc.

3. m. La lengua española, en oposición al latín o a otras lenguas no romances.

${ }^{30}$ La lengua vulgar naturalmẽte con el tiempo fe envejeçe, i muda, i en ciento o docientos años fe trueca de manera, que muchas palauras della no fe entienden, como fi fueran vocablos de lengua peregrina, ou estrangera [8, c. 176]. De la lengua Francefa, i mas a la larga de la Tudefca lo prueua bien Iufto Lipfio [...]. Efto mifmo efperimentamos en nueftra lengua cada dia, i lo vemos en los libros, que de cien años atras fe efcriuieron, que mientras mas antiguos parecen, quando fe leen, de otra lengua. Muchos de los vocablos no entendemos con propriedad lo que fignifican, fino por lo que precede, o fe figue venimos en algun conocimiento dellos. Los modos de decir, el eftilo es otro, del que oi fe vfa, i aun los tiempos de los verbos fon algunos diferentes. [...] Para mueftra defto en nueftra lengua Caftellana pondre algunos pocos de muchos, que pudiera, facados del Fuero Juzgo, de las Partidas, Hiftoria del Rei Don Alonfo, i del Infante Don Manuel [8, c. 178].

${ }^{31}$ qualquiera lengua tiene dos partes principales [...] los vocablos, i la Gramatica, aquellos fon como la materia, i efta como la forma [8, c. 255].

32 Auiendo vifto pues como los vocablos Efpañoles decienden de los Latinos, tambien es jufto trate algo de la Gramatica. Porque la femejança, que entrefi tienen las gramatica Caftellana con la Italiana, i ambas con la Latina, no fe puede mejor ver, que declinãdo algunos nombres, i conjugando algun verbo de todas tres lenguas, porque por efta via fe vendra en maior conocimiento lo que tienen de femejança, i en lo que fe apartan, para efto pufe aqui lo vno, i lo otro. Con diferentes letras. La primera es Latina, la segunda Efpañola, la tercera italiana.

Nominatiuo Genitiuo Datiuo Acufatiuo Vocatiuo Ablatiuo

Poeta, Poetae, poetae, Poetam, ò Poeta, à Poeta, el Poeta, del Poeta, al Poeta, el Poeta, ò Poeta, del Poeta, il poeta, del poeta, al poeta, il poeta o poeta, dal poeta. [...]

Ego, Mei, Mihi vel mi, Me, a Me, io, de Mi, a Mi, Me, de Mi, io, di me, a Me, me, da me [...]

affi Caftellanos, como Italianos fe diftinguen los cafos por los articulos, porque todos los cafos fon femejantes; lo que nos diferenciamos es en el plural, que nofotros fiempre lo acabamos en S, i ellos en I. Primera conjugacion. Indicatiuo

Prefens Amo, amas, amat, amamus, amatis, amant. Amo, amas, ama, amamos, amais, aman. Amo, ami, ama, amiamo, amate, amano. [...]

Plufquam Amaueram, amaueras, amauerat, amaueramus, amaueratis, amauerant. Auia

perf. amado, auias amado, auiamos amado, auiais amado, auian amado. Haueuo amato, haueui amato, haueua amato, haueuamo amato, haueuate amato, haueuano amato [8, c. 255-256].

${ }_{33}$ Con que claramente fe vee, que no es particular la gramatica Caftellana fino vna con la Italiana i nacida quando ella, i como ella de vna mesma madre la lengua Latina. Pondre otro exemplo en la oracion [8, c. 258-259].
} 
становления современной романистики, создавая основу сравнительной грамматики романских языков.

Приходится, однако, признать сохранение иерархического видения языков у испанского филолога: он последовательно сопоставляет с латынью лишь испанский и итальянский, спорадически обращается к французскому, но не приводит сведений о других романских языках, упоминаемых в трактате.

Существенная характеристика сочинения Б. де Альдрете - комплекс черт, неотъемлемых для филологических сочинений.

Для Альдрете неразрывна связь языка и его письменности ${ }^{34}$ : исчезновение письменности он объясняет исчезновением языка. Автора интересует графика: он демонстрирует сходство и отличия латинского и греческого алфавитов; сравнивает передачу звуков в романских языках $[8, \mathrm{c}$. 241-244], уделяет внимание начертанию графем.

Испанский филолог рассматривает письменные тексты как свидетельства языковой ситуации и состояния языка. В трактате есть примеры дороманской, латинской и ранней кастильской эпиграфики. Так, он приводит латинский текст, отражающий билингвизм эпохи романизации $[8, \mathrm{c}$. 93]. Латинские тексты вестготской эпохи характеризует как единственный источник знаний об идущих языковых процессах ${ }^{35}$. Для иллюстрации подвижности языка он приводит параллельные тексты (латинский, испанский) эпитафии середины XIII в. "en la capilla Real de Seuilla al Santo Rei Don Fernando" [8, с. 183-184]; цитирует "Siete Partidas" [8, с. 186).

Привлекает внимание попытка Альдрете при датировке исторического события опереться на факты истории языка: фонетический процесс (t > d) [8, c. 342], данные латинской эпиграфики [8, c. 345].

Трактат свидетельствует о глубоком знании испанским филологом предшествующей традиции. Он обращается к необычайно широкому кругу грамматистов и лексикографов, риторов, философов, писателей, поэтов, историков, отцов церкви, теологов - античных, раннехристианских, средневековых, ренессансных, - сопровождая огромное количество цитат и все упоминания авторов (более 100) скрупулёзными ссылками на полях трактата.

Немалое внимание уделено в трактате важному аспекту романской филологии - социолингвистической проблематике на разных этапах существования языка. Альдрете касается территориального, социального и функционального варьирования испанского языка. Пишет об образцовой речи королевского двора и университета (представляющей норму сложившегося к этому времени унифицированного национального литературного испанского языка), отличающейся от диалектов. Сообщает о диалектных зонах: выделяет Старую Кастилию, Новую Кастилию, Эстремадуру, Андалусию. Отмечает различия городской и сельской, письменной и устной речи ${ }^{36}$.

Особенно важна для Б. де Альдрете тема, предвосхищающая актуальную для романской филологии проблематику национальных вариантов. Он включает в сочинение по истории языка вопросы, связанные с распространением и ролью испанского языка за пределами Испании, особенно в Новом Свете, проводит параллель между Римской империей и современной Испанией, различия латыни Рима и провинций сравнивает с различиями romance Толедо и других частей Испании, тем более территорий за её пределами ${ }^{37}$.

\footnotetext{
${ }^{34}$ Recibiendo vna nacion otra lengua, con ella viene, que admita juntamente la letra con que fe escriue, i fe pierde el lenguaje, pierde tambien la forma de la letra, con que lo efcriuia [8, c. 241].

${ }^{35}$ en los quales hallamos con claridad los indicios, i mueftras de la lengua, que fe vfaua Latina corrompida, qual oi la ufamos, i della no fe hallan raftros mas antiguos $[8$, c. 154$]$

${ }^{36}$ eftos [dialectos] [...] confiften en vna cierta propiedad en el hablar [...] bien que la lengua fea toda vna. [...] eftos modos de hablar fon diuerfos en vna mifma conforme la variedad, i diverfidad de los lugares [...]. Los que andan en la Corte, i eftudian en vniuerfidades tienen desto gran experiencia, porque concurriendo a eftas partes mucha gente de diuerfas partes, i que habla vna mifma lengua Caftellana, en poco tiempo con alguna conuertencia fe conoce, qual es de Caftilla la vieja, qual de la Nueua, quien es de Eftramadura, quien de Andalucia [...]. la gente de la ciudad fe diferencia dela del campo [...]. en la variedad de la lengua, que con fer una mifma, por ella como por la vifta fe conoce quien habla, o cuios fon los efcritos, que fe leen [8, c. 190-192].

${ }^{37}$ Crefcio con efto la lengua Latina en las prouincias, si bien notan pura i elegante como en Roma, donde ella era natural [...]. Lo mifmo fucede oi en el Romance, que fin duda fe da mejor alos de Toledo, que alos de otras partes, i mucho menos fuera de Efpaña, Pues ia fi es aprendido por arte, fin tener trato con Español, de todo punto parece otro lenguaje [8, c. 56].
} 
Проведённый анализ сочинения Б. де Альдрете позволил прийти к следующим выводам.

1. История языка излагается в связи с историей страны. Внешней истории языка, особенно раннему её этапу, уделено значительное место. На всех этапах развития языка затрагивается социолингвистическая проблематика. Альдрете эксплицирует идею подвижности языка, основной причиной изменений считает языковые контакты. Автор трактата приближается к идее периодизации истории языка.

2. Представив внешнюю историю, Альдрете переходит к внутренней - к изменениям в языковой системе. В описании фонетики автор трактата примыкает к ряду ренессансных лингвистов, положивших начало исторической фонетике: выявляет регулярные фонетические процессы, сопоставляет фонетические системы родственных языков. Отмечаются изменения в морфологии имени и глагола. Большое внимание уделяется источникам испанской лексики.

3. Наряду со всесторонним изложением формирования и раннего этапа истории испанского (кастильского), Альдрете касается формирования ареалов других иберо-романских языков: португальского, каталанского, галисийского.

4. Не ограничиваясь собственно испанской и даже иберо-романской проблематикой, Альдрете помещает явления истории испанского языка в широкий романский контекст. Автор одного из первых описаний истории конкретного языка считает историчность универсальным свойством языка. Он предлагает модель сопоставительного описания романских языков, объединяя типологический и исторический подходы в описании, создавая основу сравнительной грамматики романских языков, это знаменует начало современной романистики.

5. У Б. де Альдрете складывается понятие "романский язык», встречается термин «романизованный». Он эксплицирует понимание романизации как перехода на латынь в результате усвоения римского образа жизни, римской культуры. Автор возводит романские языки к разговорной латинской речи обычных носителей латыни (то есть к народной латыни), рассматривает социолингвистические аспекты функционирования латыни. Альдрете выявляет значение первых веков после падения Римской империи как времени формирования романской речи. Характерными чертами романской речи автор считает изменения в морфологии имени и глагола (то есть аналитизм романских языков).

6. Сочинение Б. де Альдрете содержит обширную «филологическую составляющую». Автор обращается к письменным источникам (памятникам разных эпох: примерам доримской и римской эпиграфики, ранних романских текстов). Глубокое знание предшествующей филологической традиции сопровождается использованием элементов научного аппарата (корректным цитированием и ссылками на множество источников).

Таким образом, трактат Б. де Альдрете вносит существенный вклад в разработку современной модели описания истории языка и является первым сочинением, которое охватывает всю проблематику романской филологии и закладывает её основы как научной дисциплины.

(C) Косарик М.А., 2020

\section{Список литературы}

1. Алисова Т.Б. Введение в романскую филологию /Т.Б. Алисова, Т.А. Репина, М.А. Таривердиева. Москва: Издательство «Высшая школа», 2007. 453 [5] с.

2. Бурсье Э. Основы романского языкознания / Пер. с фр. под ред. Д.Е. Михальчи. Москва: УРСС, 2004. 671 с.

3. Жолудева Л.И. История итальянского языка: взгляд из XVI века // Stephanos. 2016. Т. 5. № 19. С. 67-75.

4. Косарик М.А. Программа учебной дисциплины «Введение в романскую филологию» // Stephanos. 2018. Т. 29. № 3. C. $162-179$.

5. Косарик М.А. Описание языковой системы в ранних лингвистических памятниках Португалии: В рамках проекта «Лингвистическая доктрина Португалии XVI-XVII веков: Теория и практика описания языка». Т. I: Фонетика. Морфемика. Морфология именных частей речи /М.А. Косарик. Москва: Макс Пресс, 2013. 228 с.

6. Косарик М.А. Проблематика общего языкознания в трактате 1606 г. о происхождении испанского языка Б. де Альдрете из истории лингвистических идей // Вестник Томского государственного педагогического университета. 2020 . № 5. C. $133-141$. 
7. Михайлова Е.Н. Два взгляда на проблему языка: Жак Дюбуа (1531) и Шарль де Бовель (1533) // Этапы развития романских языков: от языка живого общения к национальному языку. Межвузовский сборник научных трудов / Михайлова Е.Н. Москва. 2019. С. 138-145.

8. Aldrete B.J. de. Del origen y principio de la lengua castellana o romance que oi se usa en España. Por el doctor Bernardo Aldrete /B.J. de Aldrete. Roma: Acerca de Carlo Wilietto, 1606. 371 (25) p.

9. Bahner W. La lingüística española del Siglo de Oro /W. Bahner. Madrid: Editorial Ciencia Nueva, 1966. 202 p.

10. Gauger H.M. La conciencia lingüística en el Siglo de Oro [Электронный pecypc]. - URL: https://cvc.cervantes.es/Literatura/aih/ pdf/09/aih_09_1_006.pdf (дата доступа 08.08.2020).

11. Guitarte G.L. La Dimensión Imperial Del Español En La Obra De Aldrete: Sobre La Aparición Del Español De América En La Lingülstica Hispánica // Historiographia linguistica. 1984. T. 11. №. 1-2. Pp. 129-187.

12. Kossarik M. Amplificação dos fins da descrição da língua como fator da evolução do cânone gramatical (do cânone único à diversificação de tipos da descrição gramatical - obras portuguesas dos séculos XVI e XVII) // Atti del XXVIII Congresso internazionale di linguistica e filologia romanza (Roma, 18-23 luglio 2016). Vol. 2 / Kossarik M. Strasbourg. 2018. Pp. 1672-1682.

13. Kossarik M. Concepciones pre-coserianas en los monumentos lingüísticos portugueses de los siglos XVI y XVII // ProcessesKompetenz-Funktion-Variation: Linguistica Coseriana V / Kossarik M. Frankfurt am Main. 2017. Pp. 351-367.

14. Kossarik M. Problemática lexicológica em gramáticas, tratados e diálogos da língua dos séculos XVI e XVII // Confluência. Revista do Instituto da Língua Portuguesa. 2018. № 55. Pp. 246-283.

15. Kossarik M. Universalização de conceitos linguísticos como etapa da consolidação da ciência - contribuição dos filólogos portugueses // Confluência. Revista do Instituto da Língua Portuguesa. 2015. №49. Pp. 162-200.

16. Kukenheim L. Contributions a l'histoire de la grammaire italienne, espagnole et francaise a l'epoque de la Renaissance (Romance reprints) /L. Kukenheim. Amsterdam: Antwerpen De Vries, 1932. 232 p.

17. Lapesa R. Historia de la lengua española /R. Lapesa. Madrid: Editorial Gredos, S.A., 1981. 690 p.

18. Lledó-Guillem V. La obra de Bernardo de Aldrete en el contexto catalanohablante: imperialismo frente a nacionalismo lingüístico // Hispanic research journal. 2015. T. 16. №. 3. Pp. 191-207.

19. Molina Redondo J.A. de. Ideas lingüisticas de Bernardo de Aldrete // Revista de Filología Española. 1968. №51. Pp. 183-207.

20. Nieto Jiménez L. La política lingüística en el renacimiento español // Letras.1995. n 31-32. Pp. 5-29.

21. Ridruejo E. Los tratados de historia del español bajo el reinado de Carlos IV: las obras de Vargas Ponce y Martínez Marina [Электронный pecypc]. - URL: http://www.cervantesvirtual.com/nd/ark:/59851/bmcst809 (дата доступа 08.08.2020).

\section{References}

1. Alisova, T.B. Vvedenie v romanskuiu filologiiu [Introduction to Romance Philology] /T.B. Alisova, T.A. Repina, M.A. Tariverdieva. Moscow: Vysshaia Shkola, 2007. 453 [5] c. (In Russian).

2. Bourciez, E. Osnovy romanskogo iazykoznaniia [Fundamentals of Romance linguistics] / Translated from the French edited by D.E. Mikhal'chi. Moscow: URSS, 2004. 671 p. (In Russian).

3. Zholudeva, L.I. Istoriia ital'ianskogo iazyka: vzgliad iz XVI veka [The History of the Italian Language: a Sight from the 16th century] // Stephanos. 2016. T. 5. № 19. Pp. 67-75. (In Russian).

4. Kosarik, M.A. Programma uchebnoi distsipliny "Vvedenie v romanskuiu filologiiu [The Program of the Academic Discipline "Introduction to Romance Philology"] // Stephanos. 2018. T. 29. № 3. Pp. 162-179.

5. Kosarik, M.A. Opisanie yazykovoi sistemy v rannikh lingvisticheskikh pamiatnikakh Potugalii. Tom I. Fonetika. Morfemika. Morfologiia imennykh chastei rechi [Description of language system in early Portuguese linguistic treatises. Vol. I. Phonetics. Morphemics. Morphology of nominal parts of speech]. / M.A. Kosarik. Moscow: MAKS Press, 2013. 228 p. (In Russian).

6. Kosarik, M.A. Problematika obshchego iazykoznaniia v traktate 1606 g. o proiskhozhdenii ispanskogo iazyka B. de Al'drete iz istorii lingvisticheskikh idei [General linguistic issues in B. de Aldrete's treatise on the origins of Spanish (1616): from the history of linguistic thought] // Vestnik Tomskogo gosudarstvennogo pedagogicheskogo universiteta [Tomsk State Pedagogical University Bulletin]. 2020. № 5. Pp. 133-141. (In Russian).

7. Mikhailova, E.N. Dva vzgliada na problemu iazyka: Zhak Diubua (1531) i Sharl' de Bovel' (1533) [Two views on the problem of language: Jacques Dubois (1531) and Charles de Bovelles (1533)] // Etapy razvitiia romanskikh iazykov: ot iazyka zhivogo obshcheniia k natsional'nomu iazyku. Mezhvuzovskii sbornik nauchnykh nrudov [Intercollegiate collection of scientific papers] / Mikhailova E.N. Moscow. 2019. Pp. 138-145. (In Russian).

8. Aldrete, B.J. de. Del origen y principio de la lengua castellana o romance que oi se usa en España. Por el doctor Bernardo Aldrete [The origin and beginning of the Castilian language, or Romance language, that is spoken in Spain. By Dr. Bernardo Aldrete] /B.J. de Aldrete. Rome: By Carlo Wilietto, 1606. 371 (25) p.

9. Bahner, W. La lingüística española del Siglo de Oro [Spanish linguistics of the Golden Age] / W.Bahner. Madrid: Editorial Ciencia Nueva, 1966. 202 p. (In Spanish).

10. Gauger, H.M. La conciencia lingüística en el Siglo de Oro [Linguistic awareness in the Golden Age]. - URL: https://cvc.cervantes. es/Literatura/aih/pdf/09/aih_09_1_006.pdf (Date of access 08.08.2020). (In Spanish).

11. Guitarte, G.L. La Dimensión Imperial Del Español En La Obra De Aldrete: Sobre La Aparición Del Español De América En La Lingülstica Hispánica [The Imperial Dimension of Spanish in Aldrete’s Work: On the Appearance of American Spanish in Hispanic Linguistics] // Historiographia linguistica. 1984. T. 11. №. 1-2. Pp. 129-187. (In Spanish).

12. Kossarik, M. Amplificação dos fins da descrição da língua como fator da evolução do cânone gramatical (do cânone único à diversificação de tipos da descrição gramatical - obras portuguesas dos séculos XVI e XVII) [Widening the range of language description aims as a factor of evolution of grammatical canon (from single canon to a number of description types: XVI-XVII cc. 
Portuguese linguistic writings)] // Atti del XXVIII Congresso internazionale di linguistica e filologia romanza (Roma, 18-23 luglio 2016). Vol. 2 [Proceedings of the XXVIII International Congress on Romance Philology (Rome, July 18-23, 2016). Vol. 2] / Kossarik M. Strasbourg. 2018. Pp. 1672-1682. (In Portuguese).

13. Kossarik, M. Concepciones pre-coserianas en los monumentos lingüísticos portugueses de los siglos XVI y XVII [Pre-Coserian conceptions in XVI-XVII Portuguese linguistic writings]. // Processes-Kompetenz-Funktion-Variation: Linguistica Coseriana V [Processes, Competence, Function, Variation: Coserian Linguistics V] / Kossarik M. Frankfurt am Main. 2017. Pp. 351-367. (In Spanish).

14. Kossarik, M. Problemática lexicológica em gramáticas, tratados e diálogos da língua dos séculos XVI e XVII [Textological issues in XVI-XVII cc. grammars, treatises and dialogues on language] // Confluência. Revista do Instituto da Língua Portuguesa [Confluência. Journal of the Institute of Portuguese language]. 2018. № 55. Pp. 246-283. (In Portuguese).

15. Kossarik, M. Universalização de conceitos linguísticos como etapa da consolidação da ciência - contribuição dos filólogos portugueses [Universalization of linguistic concepts as a stage in the making of language science: the contribution of Portuguese philologists] // Confluência. Revista do Instituto da Língua Portuguesa [Confluência. Journal of the Institute of Portuguese language]. 2015. №49. Pp. 162-200. (In Portuguese).

16. Kukenheim, L. Contributions a l'histoire de la grammaire italienne, espagnole et francaise a l'epoque de la Renaissance [Contributions to the history of Italian, Spanish and French grammar during the Renaissance period] (Romance reprints) /L. Kukenheim. Amsterdam: Antwerpen De Vries, 1932. 232 p. (In French).

17. Lapesa, R. Historia de la lengua española [History of the Spanish language] /R. Lapesa. Madrid: Editorial Gredos, S.A., 1981. 690 p. (In Spanish).

18. Lledó-Guillem, V. La obra de Bernardo de Aldrete en el contexto catalanohablante: imperialismo frente a nacionalismo lingüístico [Bernardo de Aldrete's work in the Catalan-speaking context: imperialism versus linguistic nationalism] // Hispanic research journal. 2015. T. 16. №. 3. Pp. 191-207. (In Spanish).

19. Molina, Redondo J.A. de. Ideas lingüisticas de Bernardo de Aldrete [The Linguistic Ideas of Bernardo de Aldrete] // Revista de Filología Española [Journal of Spanish Philology]. 1968. №51. Pp. 183-207. (In Spanish).

20. Nieto, Jiménez L. La política lingüística en el renacimiento español [Language Policy in the Spanish Renaissance] // Letras.1995. $n^{\circ}$ 31-32. Pp. 5-29. . (In Spanish).

21. Ridruejo E. Los tratados de historia del español bajo el reinado de Carlos IV: las obras de Vargas Ponce y Martínez Marina [Treatises on the history of Spanish under the reign of Carlos IV: the works of Vargas Ponce and Martínez Marina], www. cervantesvirtual.com/nd/ark:/59851/bmcst809 (Date of access 08.08.2020). (In Spanish).

\section{Сведения об авторе:}

Косарик Марина Афанасьевна - заведующая кафедрой романского языкознания филологического факультета МГУ имени М.В. Ломоносова, доктор филологических наук, профессор. Сфера научных интересов: романское языкознание, романские языки, история романских языков, португальский язык, лингвистическая историография.

E-mail: olissipo@yandex.ru

Конфликт интересов: Автор заявляет об отсутствии конфликта интересов.

\section{About the author:}

Marina A. Kossarik - Head of Department of Romance linguistics of the Faculty of Philology of the Lomonosov Moscow State University, Doctor of Philology, Professor (Moscow, Russia). Spheres of research and professional interest: Romance linguistics, Romance languages, history of Romance languages, Portuguese language, linguistic historiography.

E-mail: olissipo@yandex.ru

Conflicts of interest: The author declares absences of conflicts of interest. 